\title{
Psychological management in chronic headache
}

Kenneth A Holroyd

From The European Headache and Migraine Trust International Congress

London, UK. 20-23 September 2012

Behavioral treatments programs for headache and the patient materials (manuals, audiotapes) used in these programs will be described. Various formats for administering behavioral treatments (home-based, phone-based) will be described. Modifications of behavioral management programs for chronic headache and for use in a multidisciplinary team approach rehabilitation of chronic headache will be addressed

Published: 21 February 2013

doi:10.1186/1129-2377-14-S1-011

Cite this article as: Holroyd: Psychological management in chronic

headache. The Journal of Headache and Pain 2013 14(Suppl 1):O11.

Submit your manuscript to a SpringerOpen ${ }^{\circ}$ journal and benefit from:

$\checkmark$ Convenient online submission

- Rigorous peer review

- Immediate publication on acceptance

- Open access: articles freely available online

- High visibility within the field

- Retaining the copyright to your article

Submit your next manuscript at $\gg$ springeropen.com 